\title{
FOREIGN CURRENCY AND RUSSIAN RUBLE: WHAT DOES THE BALANCE OF PAYMENTS TELL US? ${ }^{1}$
}

\author{
A.Bozhechkova, P. Trunin
}

The BOP (Balance of Payments) statistics for Q1 2016 show considerable shrinkage of the current account surplus due to a decline in exports while imports saw their decline rate slow down. At the same time, the private sector saw capital outflow decrease strongly. As a result, even though the trade balance dropped, the rouble did not depreciate. Moreover, the rouble exchange rate rebounded to levels seen in the fall of 2015 as crude prices went up.

According to the Bank of Russia's preliminary assessment of the BOP in January-March 2016, the current account balance stood positive at $\$ 11.7 \mathrm{bn}$, declining by $61 \%$ (by $\$ 18.3 \mathrm{bn}$ ) from Q1 2015. This considerable shrinkage resulted from a decline in the trade balance because exports declined at faster pace than imports of goods and services.

In Q1 2016, exports of goods were down by 34.3\% from Q1 2015 (from $\$ 90.2 \mathrm{bn}$ to $\$ 59.3 \mathrm{bn}$ ), including exports of crude oil (by $38.3 \%$ to $\$ 14.0 \mathrm{bn}$ ), natural gas (by $30.7 \%$ to $\$ 7.9 \mathrm{bn}$ ), due to falling global prices of energy-carrying resources. However, imports of goods at the same period dropped by only $15.4 \%$ (from $\$ 44.7 \mathrm{bn}$ to $\$ 37.8 \mathrm{bn}$ ) due to a weakening rouble and aggregate

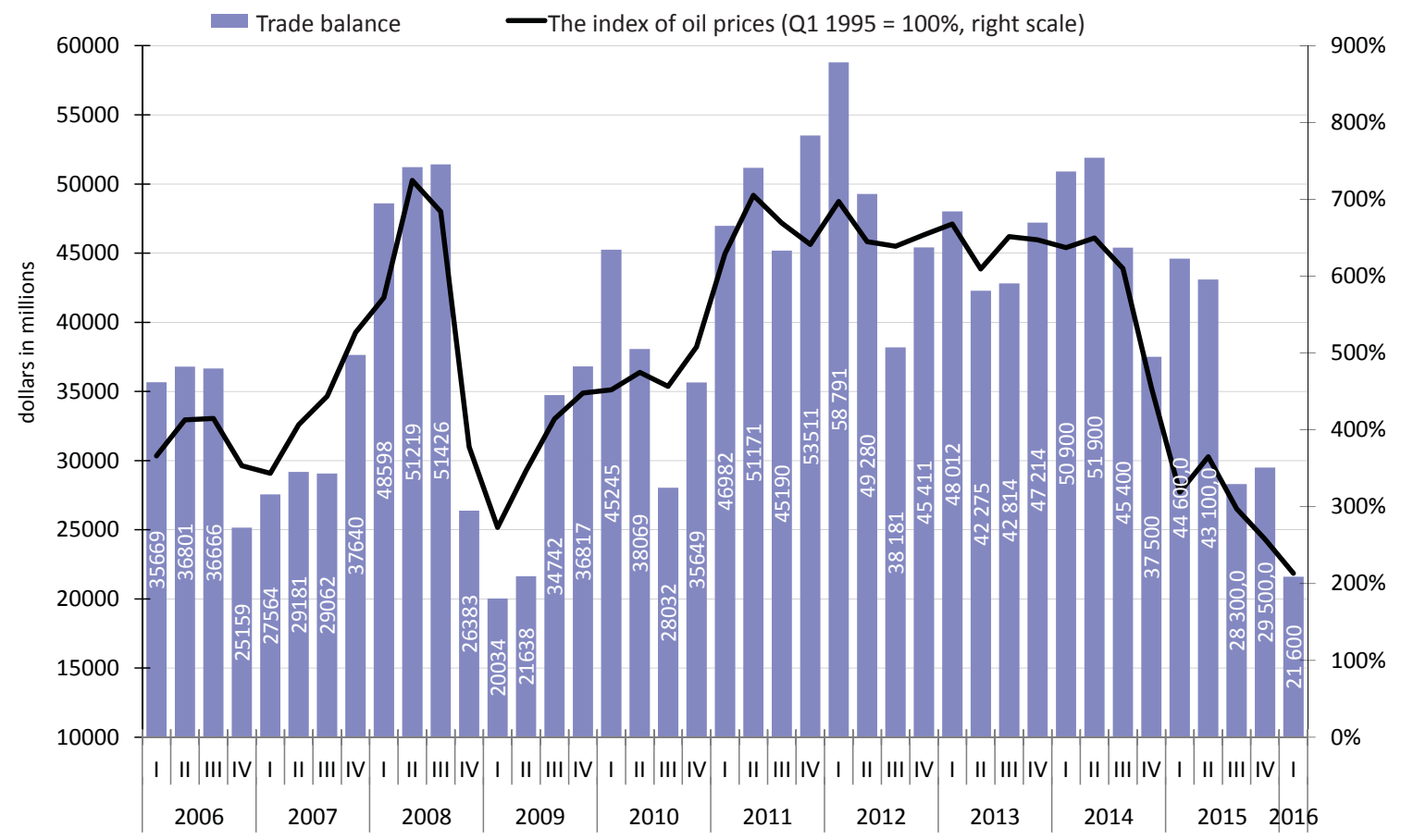

Sources: Bank of Russia, Gaidar Institute's own calculation.

Fig. 1. Russia's trade balance and global oil price index in 2006-2015

1 This paper was originally published in Online Monitoring of Russia's Economic Outlook No.6(24). 
demand. As a result, positive trade balance was down 52.5\% (from $\$ 45.5 \mathrm{bn}$ to $\$ 21.6 \mathrm{bn}$ ) (Fig. 1).

The dynamics of the rest of the current account items prevented positive balance from declining. For example, the service balance deficit in Q1 2016 stood at $\$ 4.7 \mathrm{bn}$, declining (in absolute value) by $43.4 \%$ from Q1 2015. Imports of services dropped by $28.5 \%$ to $\$ 14.3 \mathrm{bn}$ mainly because the Russians cut their international travel costs, and exports of services fell by $18.8 \%$ to $\$ 9.5 \mathrm{bn}$.

The compensation of employees balance dropped by $46.7 \%$ to $-\$ 0.8 \mathrm{bn}$ (-\$1.5bn in Q1 2015). The investment income balance deficit was down $29.2 \%$ from the same period of 2015 (from $-\$ 4.8 b n$ to $-\$ 3.4 \mathrm{bn}$ ) due to decline in costs of servicing external debts that were reduced. Investment income receivable dropped by $23.9 \%$ (from $\$ 8.8 \mathrm{bn}$ to $\$ 6.7 \mathrm{bn}$ ) due to shrinkage of foreign assets held by the private sector, that were used to meet external obligations. The income payable by non-financial enterprises declined by $28.2 \%$ ( $\$ 7.9 \mathrm{bn})$. However, the situation in the banking sector was characterized by an increase in income receivable from \$1.1bn in Q1 2015 to \$2.5bn in Q1 2016.

The decline of BOP current account surplus was attended by a comparable shrinkage of financial account deficit that stood at \$7.5bn in Q1 2016 (versus \$37.5bn in Q1 2015 and \$13.0bn in Q4 2015). In M3 2016 Russian economic agents' obligations owed to foreign economic agents dropped by $\$ 11.8 \mathrm{bn}$, whereas in Q1 2015 foreign obligations decreased by $\$ 38.7 \mathrm{bn}$. In particular, in Q1 2016 banks reduced their external obligations by $\$ 8.0 \mathrm{bn}$ (by $\$ 24.5 \mathrm{bn}$ in Q1 2015) by making repayments on previously accumulated debts. The non-bank sector reduced their external obligations by $\$ 1.3 \mathrm{bn}$ (by $\$ 7.3 \mathrm{bn}$ in Q1 2015). While in Q1 2015 foreign direct investment to the non-bank sector amounted to $\$ 2.8 \mathrm{bn}$, in Q1 2016 they were down to $\$ 0.9 \mathrm{bn}$. Indebtedness under the item "credits and loans" rose by $\$ 0.1 \mathrm{bn}$, whereas it shrank by \$7.0bn in Q1 2015.

Note that in 2016 economic agents are due to pay $\$ 80 \mathrm{bn}(\$ 120 \mathrm{bn}$ in 2015). Next peak repayments that are due in June and in Q4 2016 will temporally push down the rouble exchange rate.

The BOP statistics show that economic agents used foreign assets to meet their obligations. Foreign assets held by residents (foreign economic agents' obligations owed to Russian economic agents) dropped by $\$ 4.3 \mathrm{bn}$ in January-March 2016 (a decline of $\$ 1.2 b n$ in Q1 2015). Foreign assets held by the banking sector contracted by $\$ 7.8 \mathrm{bn}$ (a growth of $\$ 10.3 \mathrm{bn}$ in Q1 2015). Foreign assets held by the banking sector shrank partly due to banks' payments due on foreign currency loans received from the Bank of Russia. In the period between January and March 2016, foreign currency liquidity received by credit institutions from the Bank of Russia dropped by Rb 5.6bn. Capital exports from other sectors decreased by $57.8 \%$ to $\$ 3.8 \mathrm{bn}$, of which direct and portfolio investment abroad amounted to $\$ 3.7 \mathrm{bn}$ and $\$ 0.2 \mathrm{bn}$, respectively (\$4.8bn and $\$ 1.1 \mathrm{bn}$ respectively in Q1 2015). Overall, net capital exports in the private sector stood at $\$ 7 \mathrm{bn}$, that is, more than 4.5 times below the value seen in Q1 2015 (Fig. 2).

The BOP statistics show that in Q1 2016 international reserves assets increased $\$ 2.6 \mathrm{bn}$ because the banking sector redeemed their outstanding foreign currency loans received from the regulator.

Thus, the positive trade balance contributed much less to foreign currency inflow to Russia in Q1 2016 than in Q1 2015 because exports of goods 


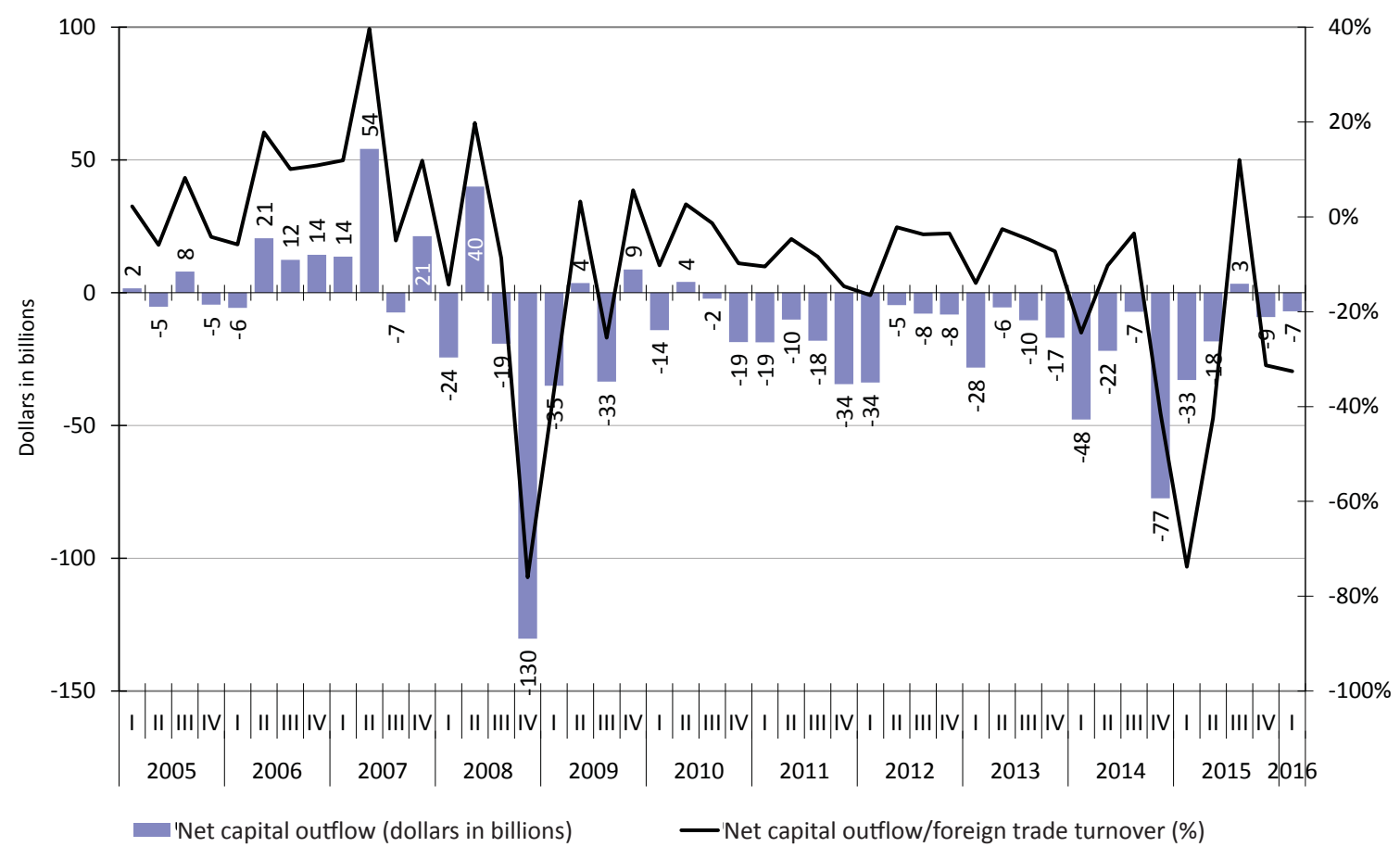

Sources: Bank of Russia, Gaidar Institute's own calculation.

Figure 2. Net capital outflow in private sector, 2005-2016

declined at faster rate than imports. Investment income receivable as well as exports of services continued to be primary source of demand for foreign currency. However, the upward effect of foreign currency inflow via these channels on the rouble exchange rate was offset by foreign currency outflow that was necessitated by external debt interest payments, as well as by payments for imports of services. In Q1 2016 banks and other sectors showed demand

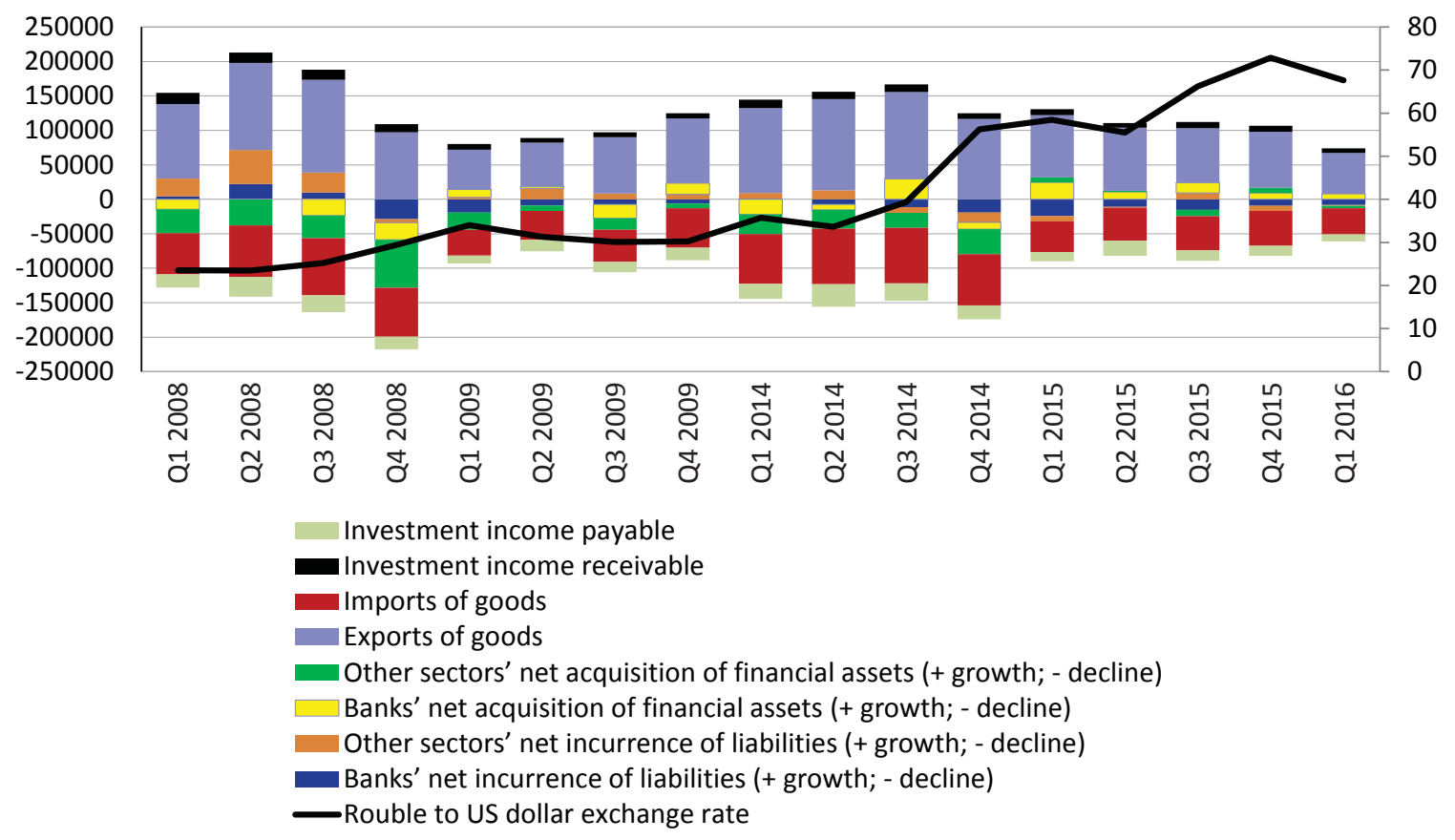

Source: Russia's Central Bank.

Fig. 3. Key sources of foreign currency supply and demand 
for foreign currency, reducing their external obligations. However, this had no serious effect on the foreign exchange market because banks reduced their foreign liabilities mostly using their foreign asset holdings (Fig. 3).

In Q1 2016, the US dollar to rouble nominal exchange rate decreased by $7.2 \%$, from 72.88 to 67.61 roubles per US dollar. As a reminder, in the second half of January 2016 the rouble was traded at 80 roubles per US dollar in the foreign exchange market. Due to stabilized inflation and a slump in the rouble nominal exchange rate in January 2016, despite a correction in February-March 2016, the rouble real effective exchange rate in Q1 2016 depreciated by 4.8\% from December 2015, reaching levels seen in January 2005. In February-March 2016 the rouble was driven up by a $13.7 \%$ spike of crude prices, to $\$ 38.64$ a barrel, in response to a decline in the US oil production, as well as over news that Russia and OPEC counties may agree on cutting oil production.

The financial account dynamics contributed to the rouble appreciation in Q1 2016. The rouble is supported by a major slowdown of capital outflow in the private sector due to stabilized geopolitical context, the Bank of Russia's moderately strict monetary policy that makes rouble assets attractive, as well as slower rates of repayment of obligations owed by banks and other sectors. Our estimates show that the current rouble real effective exchange rate is fundamentally substantiated. The Russian rouble may firm up further if prices of energy-carrying resources go up and sanctions against Russia are lifted. To counter rouble's appreciation, Russia's Central Bank may start buying foreign currency to increase its international reserves. 